\title{
4-Methylenesterols from a Sponge Theonella swinhoei
}

\section{Jheng-Kun Guo ${ }^{1,2}$, Ching-Ying Chiang ${ }^{3}$, Mei-Chin Lu ${ }^{1,4}$, Wen-Been Chang ${ }^{1,2, *}$ and Jui-Hsin Su ${ }^{1,4,5, *}$}

1 National Museum of Marine Biology \& Aquarium, Pingtung 944, Taiwan;

E-Mails: idun031177@hotmail.com (J.-K.G.); jinx6609@nmmba.gov.tw (M.-C.L.)

2 Graduate Institute of Marine Biodiversity and Evolutionary Biology, National Dong Hwa University, Pingtung 944, Taiwan

3 Center of General Studies, National Kaohsiung Marine University, Kaohsiung 811, Taiwan;

E-Mail: cyjang@webmail.nkmu.edu.tw

4 Graduate Institute of Marine Biotechnology, National Dong Hwa University, Pingtung 944, Taiwan

5 Asia-Pacific Ocean Research Center, National Sun Yat-sen University, Kaohsiung 804, Taiwan

* Authors to whom correspondence should be addressed; E-Mails: wenbeen@nmmba.gov.tw (W.-B.C.); x2219@nmmba.gov.tw (J.-H.S.); Tel.: +886-8-8825001 (ext. 3126); Fax: +886-8-8825087.

Received: 11 June 2012; in revised form: 28 June 2012 / Accepted: 11 July 2012 /

Published: 19 July 2012

\begin{abstract}
Three new 4-methylenesterols, theonellasterol K (1), acetyltheonellasterol (2) and acetyldehydroconicasterol (3), along with two known sterols, theonellasterol (4) and theonellasterone (5), were isolated from the sponge Theonella swinhoei. The structures of these compounds were elucidated on the basis of their spectroscopic data and comparison of the NMR data with those of known analogues. Compound $\mathbf{1}$ exhibited significant cytotoxic activity against HCT-116, K562 and Molt 4 cancer cell lines.
\end{abstract}

Keywords: 4-methylenesterols; sponge; Theonella

\section{Introduction}

In recent years, marine sponges have emerged as one of the most prolific sources for discovery of novel secondary metabolites [1-3]. Some of these have been found to possess several kinds of biological activities, such as cytotoxic [4,5], antimicrobial [6], and antiviral properties [7]. 4-Methylenesterols were first reported in 1981 as being obtained from two marine sponges, Theonella conica and Theonella swinhoei, from the Red Sea [8]. Marine sponges of the genus Theonella are now 
known to be a rich source of novel 4-methylene sterols [8-21]. Some of these sterols display a variety of biological activities, and pharmacological evaluation has shown them to be modulators of two well-known nuclear receptors, FXR and PXR [16-21], and cytotoxic activity [9]. Furthermore, a recently published report indicates that theonellasterol (4) is a highly selective FXR antagonist that protects against cholestatic liver injury [21]. Research into the pharmacological properties of this class of natural products is of particular interest. Our investigation of the chemical constituents of the sponge Theonella swinhoei (Figure 1) yielded three new 4-methylene sterols, theonellasterol K (1), acetyltheonellasterol (2) and acetyldehydroconicasterol (3), along with two known sterols, theonellasterol (4) [8] and theonellasterone (5) [10] (Chart 1). The structures of 1-5 were established by detailed spectroscopic analysis, including extensive examination of $2 \mathrm{D}$ NMR $\left({ }^{1} \mathrm{H}-{ }^{1} \mathrm{H}\right.$ COSY, HMQC and HMBC) correlations. The cytotoxicity of metabolites 1-5 against human colorectal carcinoma (DLD-1), human hormone-dependent breast cancer (T-47D), human colon adenocarcinoma (HCT-116), human breast adenocarcinoma (MCF-7 and MDA-MB-231), human chronic myelogenous leukemia (K562) and human T lymphoblast, acute lymphoblastic leukemia (Molt 4) was studied in order to discover bioactive compounds.

Figure 1. Sponge Theonella swinhoei.

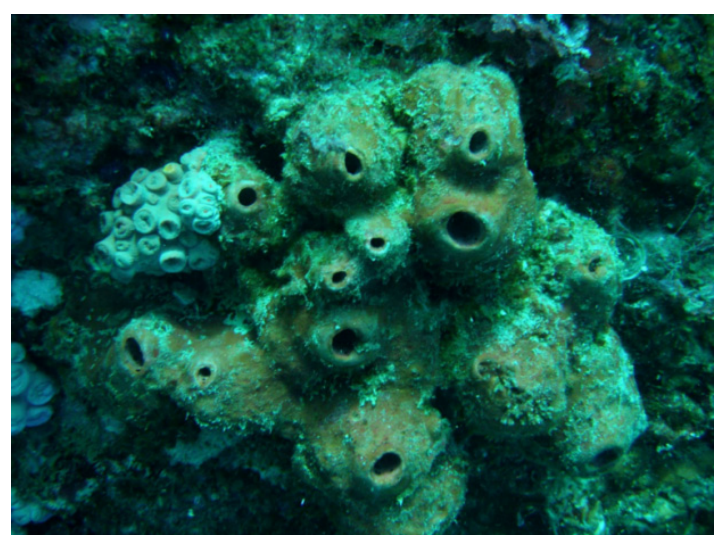

Chart 1. Structures of metabolites 1-5.
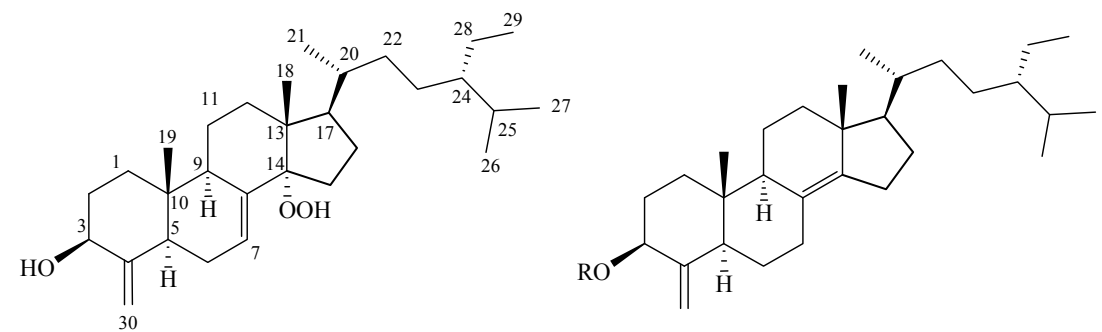

1

$$
\text { 2: } \mathrm{R}=\mathrm{Ac}
$$

$$
\text { 4: } \mathrm{R}=\mathrm{H}
$$
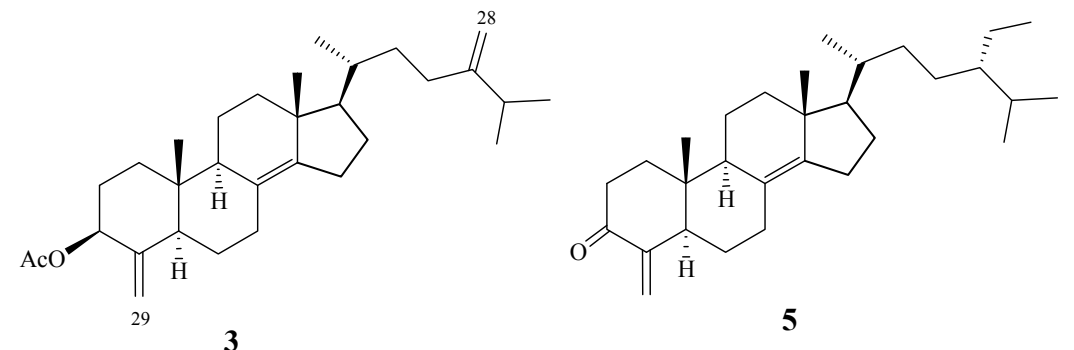


\section{Results and Discussion}

The EtOAc extract of the freeze-dried specimen was fractionated by silica gel column chromatography and the eluted fractions were further separated utilizing normal phase HPLC to yield metabolites 1-5. The new compounds were given the trivial names theonellasterol $K$ (1), acetyltheonellasterol (2) and acetyldehydroconicasterol (3). The known compounds were identified as theonellasterol (4) and theonellasterone (5).

Table 1. ${ }^{1} \mathrm{H}$ and ${ }^{13} \mathrm{C}$ NMR data for $\mathbf{1}-\mathbf{3}$.

\begin{tabular}{|c|c|c|c|c|c|c|}
\hline & \multicolumn{2}{|l|}{1} & \multicolumn{2}{|l|}{2} & \multicolumn{2}{|l|}{3} \\
\hline & $\delta_{\mathrm{H}}(J \text { in } \mathrm{Hz})^{a}$ & $\delta_{\mathrm{C}}$ (mult.) ${ }^{\mathrm{b}}$ & $\delta_{\mathrm{H}}(J \text { in } \mathrm{Hz})^{\mathrm{a}}$ & $\delta_{\mathrm{C}}$ (mult.) ${ }^{\mathrm{b}}$ & $\delta_{\mathrm{H}}(J \text { in } \mathrm{Hz})^{a}$ & $\delta_{\mathrm{C}}$ (mult.) ${ }^{b}$ \\
\hline 1 & $1.39 \mathrm{~m} ; 1.82 \mathrm{~m}$ & $37.2\left(\mathrm{CH}_{2}\right)$ & $1.38 \mathrm{~m} ; 1.80 \mathrm{~m}$ & $36.5\left(\mathrm{CH}_{2}\right)$ & $1.38 \mathrm{~m} ; 1.79 \mathrm{~m}$ & $36.5\left(\mathrm{CH}_{2}\right)$ \\
\hline 2 & $1.42 \mathrm{~m} ; 1.98 \mathrm{~m}$ & $32.7\left(\mathrm{CH}_{2}\right)$ & $1.50 \mathrm{~m} ; 1.94 \mathrm{~m}$ & $29.6\left(\mathrm{CH}_{2}\right)$ & $1.52 \mathrm{~m} ; 1.94 \mathrm{~m}$ & $29.6\left(\mathrm{CH}_{2}\right)$ \\
\hline 3 & $4.01 \mathrm{dd}(11.0,5.0)$ & $73.2(\mathrm{CH})$ & $5.15 \mathrm{dd}(12.0,5.0)$ & $74.8(\mathrm{CH})$ & $5.15 \mathrm{dd}(12.0,5.0)$ & $74.8(\mathrm{CH})$ \\
\hline 4 & & $151.9(\mathrm{C})$ & & $148.0(\mathrm{C})$ & & $148.0(\mathrm{C})$ \\
\hline 5 & $1.97 \mathrm{~m}$ & $45.1(\mathrm{CH})$ & $1.89 \mathrm{~d}(13.0)$ & $49.5(\mathrm{CH})$ & $1.90 \mathrm{~m}$ & $49.5(\mathrm{CH})$ \\
\hline 6 & $2.07 \mathrm{~m} ; 2.14 \mathrm{~m}$ & $25.1\left(\mathrm{CH}_{2}\right)$ & $1.38 \mathrm{~m} ; 1.84 \mathrm{~m}$ & $27.0\left(\mathrm{CH}_{2}\right)$ & $1.40 \mathrm{~m} ; 1.84 \mathrm{~m}$ & $27.0\left(\mathrm{CH}_{2}\right)$ \\
\hline 7 & $5.68 \mathrm{~d}(5.5)$ & $125.0(\mathrm{CH})$ & $2.25 \mathrm{~m}$ & $25.8\left(\mathrm{CH}_{2}\right)$ & $2.25 \mathrm{~m}$ & $25.8\left(\mathrm{CH}_{2}\right)$ \\
\hline 8 & & $135.5(\mathrm{C})$ & & $125.5(\mathrm{C})$ & & $125.6(\mathrm{C})$ \\
\hline 9 & $2.17 \mathrm{~m}$ & $45.4(\mathrm{CH})$ & $1.80 \mathrm{~m}$ & $49.1(\mathrm{CH})$ & $1.80 \mathrm{~m}$ & $49.1(\mathrm{CH})$ \\
\hline 10 & & $37.2(\mathrm{C})$ & & $39.8(\mathrm{C})$ & & $39.8(\mathrm{C})$ \\
\hline 11 & $1.47 \mathrm{~m} ; 1.64 \mathrm{~m}$ & $20.8\left(\mathrm{CH}_{2}\right)$ & $1.48 \mathrm{~m} ; 1.64 \mathrm{~m}$ & $20.4\left(\mathrm{CH}_{2}\right)$ & $1.48 \mathrm{~m} ; 1.64 \mathrm{~m}$ & $20.4\left(\mathrm{CH}_{2}\right)$ \\
\hline 12 & $1.62 \mathrm{~m} ; 1.82 \mathrm{~m}$ & $30.5\left(\mathrm{CH}_{2}\right)$ & $1.14 \mathrm{~m} ; 1.96 \mathrm{~m}$ & $37.3\left(\mathrm{CH}_{2}\right)$ & $1.15 \mathrm{~m} ; 1.96 \mathrm{~m}$ & $37.3\left(\mathrm{CH}_{2}\right)$ \\
\hline 13 & & $47.3(\mathrm{C})$ & & $42.7(\mathrm{C})$ & & $42.8(\mathrm{C})$ \\
\hline 14 & & $98.3(\mathrm{C})$ & & $143.1(\mathrm{C})$ & & $143.0(\mathrm{C})$ \\
\hline 15 & $\begin{array}{l}1.34 \mathrm{~m} \\
2.06 \mathrm{~m}\end{array}$ & $26.9\left(\mathrm{CH}_{2}\right)$ & $\begin{array}{c}1.75 \mathrm{~m} ; \\
2.47 \mathrm{dd}(13.5,1.0)\end{array}$ & $29.2\left(\mathrm{CH}_{2}\right)$ & $\begin{array}{c}1.77 \mathrm{~m} \\
2.47 \mathrm{~d}(14.0)\end{array}$ & $29.2\left(\mathrm{CH}_{2}\right)$ \\
\hline 16 & $1.62 \mathrm{~m} ; 2.08 \mathrm{~m}$ & $24.8\left(\mathrm{CH}_{2}\right)$ & $1.36 \mathrm{~m} ; 1.60 \mathrm{~m}$ & $24.5\left(\mathrm{CH}_{2}\right)$ & $1.36 \mathrm{~m} ; 1.59 \mathrm{~m}$ & $24.5\left(\mathrm{CH}_{2}\right)$ \\
\hline 17 & $1.85 \mathrm{~m}$ & $50.9(\mathrm{CH})$ & $1.16 \mathrm{~m}$ & $56.7(\mathrm{CH})$ & $1.17 \mathrm{~m}$ & $56.7(\mathrm{CH})$ \\
\hline 18 & $0.74 \mathrm{~s}$ & $17.0\left(\mathrm{CH}_{3}\right)$ & $0.84 \mathrm{~s}$ & $18.2\left(\mathrm{CH}_{3}\right)$ & $0.85 \mathrm{~s}$ & $18.2\left(\mathrm{CH}_{3}\right)$ \\
\hline 19 & $0.71 \mathrm{~s}$ & $13.6\left(\mathrm{CH}_{3}\right)$ & $0.62 \mathrm{~s}$ & $13.1\left(\mathrm{CH}_{3}\right)$ & $0.62 \mathrm{~s}$ & $13.1\left(\mathrm{CH}_{3}\right)$ \\
\hline 20 & $1.37 \mathrm{~m}$ & $36.3(\mathrm{CH})$ & $1.46 \mathrm{~m}$ & $34.9(\mathrm{CH})$ & $1.50 \mathrm{~m}$ & $34.4(\mathrm{CH})$ \\
\hline 21 & $0.89 \mathrm{~d}(7.0)$ & $19.0\left(\mathrm{CH}_{3}\right)$ & $0.95 \mathrm{~d}(6.5)$ & $19.2\left(\mathrm{CH}_{3}\right)$ & $0.96 \mathrm{~d}(6.5)$ & $19.1\left(\mathrm{CH}_{3}\right)$ \\
\hline 22 & $1.00 \mathrm{~m} ; 1.40 \mathrm{~m}$ & $34.0\left(\mathrm{CH}_{2}\right)$ & $1.06 \mathrm{~m} ; 1.41 \mathrm{~m}$ & $33.7\left(\mathrm{CH}_{2}\right)$ & $1.24 \mathrm{~m} ; 1.60 \mathrm{~m}$ & $34.4\left(\mathrm{CH}_{2}\right)$ \\
\hline 23 & $1.04 \mathrm{~m} ; 1.34 \mathrm{~m}$ & $26.7\left(\mathrm{CH}_{2}\right)$ & $1.04 \mathrm{~m} ; 1.32 \mathrm{~m}$ & $26.2\left(\mathrm{CH}_{2}\right)$ & $1.90 \mathrm{~m} ; 2.08 \mathrm{~m}$ & $30.8\left(\mathrm{CH}_{2}\right)$ \\
\hline 24 & $0.94 \mathrm{~m}$ & $46.0(\mathrm{CH})$ & $0.92 \mathrm{~m}$ & $46.1(\mathrm{CH})$ & & $156.9(\mathrm{C})$ \\
\hline 25 & $1.68 \mathrm{~m}$ & $29.0(\mathrm{CH})$ & $1.68 \mathrm{~m}$ & $28.9(\mathrm{CH})$ & $2.24 \mathrm{~m}$ & $33.8(\mathrm{CH})$ \\
\hline 26 & $0.81 \mathrm{~d}(7.0)$ & $18.9\left(\mathrm{CH}_{3}\right)$ & $0.82 \mathrm{~d}(8.5)$ & $19.0\left(\mathrm{CH}_{3}\right)$ & $1.03 \mathrm{~d}(7.0)$ & $21.9\left(\mathrm{CH}_{3}\right)$ \\
\hline 27 & $0.83 \mathrm{~d}(7.0)$ & $19.6\left(\mathrm{CH}_{3}\right)$ & $0.83 \mathrm{~d}(7.0)$ & $19.5\left(\mathrm{CH}_{3}\right)$ & $1.04 \mathrm{~d}(7.5)$ & $22.0\left(\mathrm{CH}_{3}\right)$ \\
\hline 28 & $1.14 \mathrm{~m} ; 1.32 \mathrm{~m}$ & $23.0\left(\mathrm{CH}_{2}\right)$ & $1.16 \mathrm{~m} ; 1.32 \mathrm{~m}$ & $23.0\left(\mathrm{CH}_{2}\right)$ & $4.67 \mathrm{~s} ; 4.73 \mathrm{~s}$ & $105.9\left(\mathrm{CH}_{2}\right)$ \\
\hline 29 & $0.86 \mathrm{t}(7.5)$ & $12.3\left(\mathrm{CH}_{3}\right)$ & $0.86 \mathrm{t}(7.5)$ & $12.3\left(\mathrm{CH}_{3}\right)$ & $4.60 \mathrm{~s} ; 4.89 \mathrm{~s}$ & $103.7\left(\mathrm{CH}_{2}\right)$ \\
\hline 30 & $4.74 \mathrm{~s} ; 5.18 \mathrm{~s}$ & $103.6\left(\mathrm{CH}_{2}\right)$ & $4.60 \mathrm{~s} ; 4.89 \mathrm{~s}$ & $103.7\left(\mathrm{CH}_{2}\right)$ & & \\
\hline 3-OAc & & & $2.13 \mathrm{~s}$ & $\begin{array}{c}21.2\left(\mathrm{CH}_{3}\right) \\
170.2(\mathrm{C})\end{array}$ & $2.13 \mathrm{~s}$ & $\begin{array}{c}21.2\left(\mathrm{CH}_{3}\right) \\
170.2(\mathrm{C})\end{array}$ \\
\hline $14-\mathrm{OOH}$ & 6.79 br s & & & & & \\
\hline
\end{tabular}

${ }^{\mathrm{a}} 500 \mathrm{MHz}$ in $\mathrm{CDCl}_{3} ;{ }^{\mathrm{b}} 125 \mathrm{MHz}$ in $\mathrm{CDCl}_{3} ;{ }^{\mathrm{c}} J$ values $(\mathrm{Hz})$ are given in parentheses; ${ }^{\mathrm{d}}$ Numbers of attached protons were deduced by DEPT experiments. 
Theonellasterol K (1) was obtained as a white amorphous solid. The HRESIMS spectrum of $\mathbf{1}$ exhibited a pseudomolecular ion peak at $m / z 481.3659[\mathrm{M}+\mathrm{Na}]^{+}$, which established a molecular formula of $\mathrm{C}_{30} \mathrm{H}_{50} \mathrm{O}_{3}$, implying six degrees of unsaturation. IR absorptions were observed at 3362 and $3251 \mathrm{~cm}^{-1}$, suggesting the presence of hydroxy groups in $\mathbf{1}$. The structure of this compound was deduced from its ${ }^{13} \mathrm{C}$ NMR and DEPT spectroscopic data (Table 1), which showed that the compound has 30 carbons, including six methyls, ten $\mathrm{sp}^{3}$ methylenes, one $\mathrm{sp}^{2}$ methylene, seven $\mathrm{sp}^{3}$ methines (including one oxymethine), one $\mathrm{sp}^{2}$ methine, three $\mathrm{sp}^{3}$ quaternary carbons and two $\mathrm{sp}^{2}$ quaternary carbons. From the ${ }^{1} \mathrm{H}$ NMR spectrum of 1 , resonances of one olefinic methine proton $(\delta 5.68, \mathrm{~d}$, $J=5.5 \mathrm{~Hz}$ ), two olefinic methylene protons ( $\delta 5.18$ and 4.74, each s) and one oxygenated methine ( $\delta 4.01$, dd, $J=11.0,5.0 \mathrm{~Hz}$ ) were observed. Moreover, the ${ }^{1} \mathrm{H}$ NMR spectrum revealed the presence of one hydroperoxy proton resonating as a broad singlet at $\delta_{\mathrm{H}} 6.79$. The planar structure and all of the ${ }^{1} \mathrm{H}$ and ${ }^{13} \mathrm{C}$ chemical shifts of $\mathbf{1}$ were elucidated by 2D NMR spectroscopic analysis, in particular ${ }^{1} \mathrm{H}-{ }^{1} \mathrm{H}$ COSY and HMBC experiments (Figure 2). From the ${ }^{1} \mathrm{H}-{ }^{1} \mathrm{H}$ COSY correlations, it was found that one ring-juncture methine proton $\mathrm{H}-5(\delta 1.97)$ and one oxymethine proton $\mathrm{H}-3(\delta 4.01)$ exhibited allylic correlations with the exomethylene protons at $\mathrm{C}-30\left(\delta_{\mathrm{H}} 4.74\right.$ and 5.18). In addition, ${ }^{1} \mathrm{H}-{ }^{1} \mathrm{H}$ COSY spectral analysis established five partial structures of consecutive proton spin systems (Figure 2). Further analysis of the HMBC correlations was employed successfully to establish the gross structure of 1 (Figure 2). Thus, 1 was found to possess two double bonds at C-7/C-8 and C-4/C-30, one hydroxy group at C-3 and one hydroperoxy group at C-14.

Figure 2. Selected ${ }^{1} \mathrm{H}-{ }^{1} \mathrm{H}$ COSY $(-)$ and $\operatorname{HMBC}(\rightarrow)$ correlations of $\mathbf{1}$.

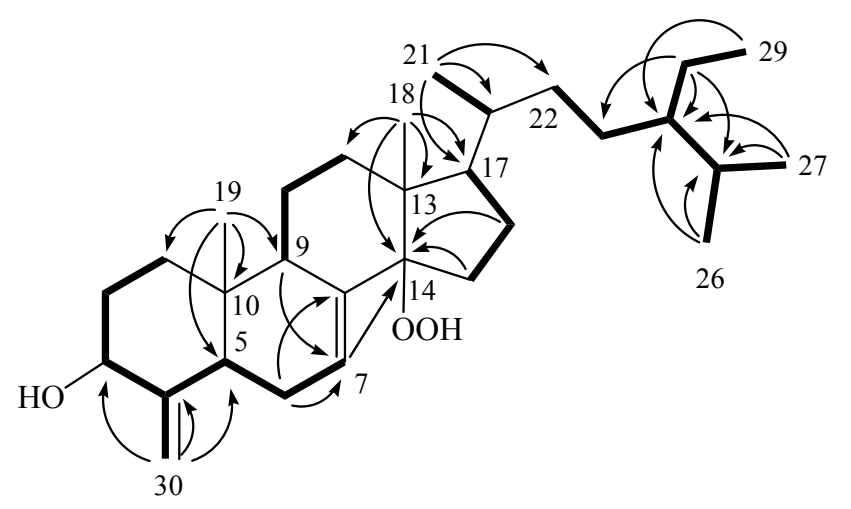

The relative configuration of $\mathbf{1}$, elucidated mainly from the NOESY spectrum, was compatible with that of 1 ascertained using molecular mechanics calculations (MM2), which suggested the most stable conformations, as shown in Figure 3. In the NOESY spectrum of $\mathbf{1}$, the NOE correlations between one of the methylene protons at $\mathrm{C}-11\left(\delta_{\mathrm{H}} 1.47\right)$ and both methyls $\left(\mathrm{H}_{3}-18\right.$ and $\left.\mathrm{H}_{3}-19\right) ; \mathrm{H}_{3}-18$ and $\mathrm{H}-20$ as well as between $\mathrm{H}_{3}-18, \mathrm{H}_{3}-19$ and $\mathrm{H}-20$ indicated that these protons adapt a $\beta$-orientation. $\mathrm{H}-5$ was found to interact with $\mathrm{H}-3$, but not with $\mathrm{H}_{3}-19$, revealing the $\beta$ orientation of the hydroxy group at C-3. Moreover, the $\alpha$-orientation of $14-\mathrm{OOH}$ was further confirmed by the lower field chemical shift of H-17 $\left(\delta_{\mathrm{H}} 1.85, \mathrm{~m}\right)$. Furthermore, the chemical shifts of the side chain from C-20 to C-29 in 1 were nearly identical to those of $\mathbf{4}$ and $\mathbf{5}$. Thus, the structure of steroid $\mathbf{1}$ was established. After determining the structure of $\mathbf{1}$, we discovered that its molecular framework has been obtained as a known 4-methylenesterol conicasterol $\mathrm{H}$, which was isolated previously from sponge Theonella swinhoei [18]. 
Figure 3. Computer-generated model of 1 using MM2 force field calculations and selected NOE correlations from $\mathrm{C}-1-\mathrm{C}-21$ of $\mathbf{1}$.

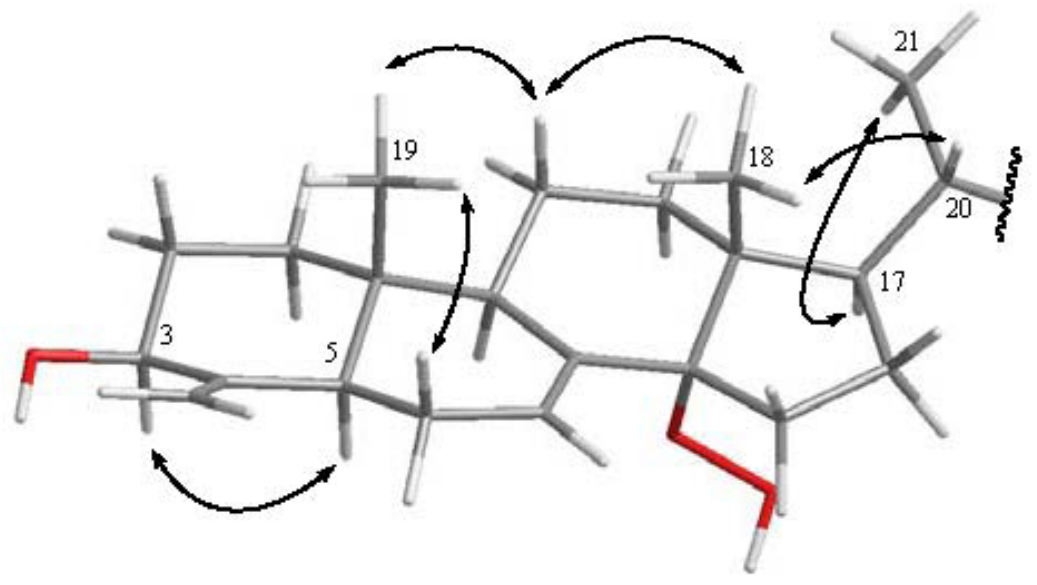

Acetyltheonellasterol (2) was isolated as a white powder with the molecular formula $\mathrm{C}_{32} \mathrm{H}_{52} \mathrm{O}_{2}$, which possesses seven degrees of unsaturation, as indicated by HRESIMS $\left(m / z\right.$ 491.3862, $\left.[\mathrm{M}+\mathrm{Na}]^{+}\right)$ and NMR spectroscopic data (Table 1). By comparison of the NMR data of $\mathbf{2}$ with those of $\mathbf{4}$, it was found that the ${ }^{1} \mathrm{H}$ and ${ }^{13} \mathrm{C}$ NMR data of $\mathbf{2}$ were very similar to those of $\mathbf{4}$, with the difference that 2 contains one more acetyl group relative to 4 . The chemical shift of H-3 in $4\left(\delta_{\mathrm{H}} 4.01\right)$ was shifted downfield $\left(\delta_{\mathrm{H}} 5.15\right)$ in $\mathbf{2}$, suggesting that $\mathbf{2}$ is the 3 -acetyl derivative of $\mathbf{4}$. We observed further that acetylation of 4 gave a product which was found to be identical to 2 by comparison of the physical and spectroscopic data. Thus, compound $\mathbf{2}$ was established as the 3-acetyl derivative of $\mathbf{4}$.

The new metabolite acetyldehydroconicasterol (3) was obtained as a white powder and possessed the molecular formula $\mathrm{C}_{31} \mathrm{H}_{48} \mathrm{O}_{2}$, as established from the HRESIMS and NMR data, implying eight degrees of unsaturation. Both the ${ }^{1} \mathrm{H}$ and ${ }^{13} \mathrm{C}$ NMR signals of $\mathbf{3}$ were found to be very closely related to those of compound 2, suggesting a very similar steroidal skeleton. By comparison of the NMR data of 3 with those of 2 (Table 1), it was found that an ethyl protons signal $\left[\delta_{\mathrm{H}} 0.86 \mathrm{t}, J=7.5 \mathrm{~Hz}\left(\mathrm{H}_{3}-29\right)\right.$; $1.16 \mathrm{~m}$ and $\left.1.32 \mathrm{~m}\left(\mathrm{H}_{2}-28\right)\right]$ in 2 was replaced by two exomethylene proton signals $\left(\delta_{\mathrm{H}} 4.73\right.$ and 4.67 , each s) in 3. The only difference observed was that the 24-ethyl side chain of 2 was replaced by two exomethylene proton signals in $\mathbf{3}$. This was further confirmed by the HMBC correlations from $\mathrm{H}_{2}-28$ to $\mathrm{C}-23, \mathrm{C}-24$, and $\mathrm{C}-25$. On the basis of the above analysis, the structure of $\mathbf{3}$ was established.

Finally, we used a 3-(4,5-dimethylthiazol-2-yl)-2,5-diphenyl tetrazolium bromide (MTT) assay to examine the cytotoxic activities of compounds 1-5 against DLD-1, T47D, HCT-116, MCF-7, MDA-MB-231, K562 and Molt 4 cancer cells. Cells were treated with different concentrations of 1-5 for $72 \mathrm{~h}$. The results showed that compound $\mathbf{1}$, the most potent of compounds $\mathbf{1}-\mathbf{5}$, exhibited cytotoxicity against DLD-1, T47D, HCT-116, MDA-MB-231, K562 and Molt 4, with $\mathrm{IC}_{50}$ s of 12.9, 12.0, 6.3, 11.5, $11.4,4.3$, and $6.3 \mu \mathrm{g} / \mathrm{mL}$, respectively. Furthermore, compound 2 exhibited weak cytotoxic activity against K562 and Molt 4 cancer cell lines (the $\mathrm{IC}_{50}$ values were 13.7 and $17.8 \mu \mathrm{g} / \mathrm{mL}$ for K562 and Molt 4, respectively). The other tested compounds were not cytotoxic $\left(\mathrm{IC}_{50}>20 \mu \mathrm{g} / \mathrm{mL}\right)$ towards the above seven cancer cell lines (Table 2). 
Table 2. Cytotoxicity $\left(\mathrm{IC}_{50} \mu \mathrm{g} / \mathrm{mL}\right)$ of compounds $\mathbf{1}-\mathbf{5}^{\mathrm{a}}$.

\begin{tabular}{cccccccc}
\hline & \multicolumn{8}{c}{ Cell Lines } \\
\cline { 2 - 8 } & DLD-1 & T-47D & HCT-116 & MCF-7 & MDA-MB-231 & K562 & Molt 4 \\
\hline $\mathbf{1}$ & 12.9 & 12.0 & 6.3 & 11.5 & 11.4 & 4.3 & 6.3 \\
$\mathbf{2}$ & $-{ }^{\mathrm{c}}$ & $-{ }^{\mathrm{c}}$ & $-{ }^{\mathrm{c}}$ & $-{ }^{\mathrm{c}}$ & $-{ }^{\mathrm{c}}$ & 13.7 & 17.8 \\
Doxorubicin $^{\mathrm{b}}$ & 0.42 & 0.28 & 0.89 & 2.2 & 1.3 & 0.14 & 0.009 \\
\hline
\end{tabular}

${ }^{a}$ Compounds 3-5 was inactive against all seven cell lines $\left(\mathrm{IC}_{50}>20 \mu \mathrm{g} / \mathrm{mL}\right) ;{ }^{b}$ Clinical anticancer drug used as a positive control; ${ }^{\mathrm{c}} \mathrm{NA}$, not active at $20 \mu \mathrm{g} / \mathrm{mL}$.

\section{Experimental Section}

\subsection{General Experimental Procedures}

Optical rotation values were measured with a Jasco P-1010 digital polarimeter. IR spectra were recorded on a Varian Digilab FTS 1000 Fourier transform infrared spectrophotometer. The NMR spectra were recorded on a Varian Mercury Plus 400 FT-NMR (or Varian Unity INOVA 500 FT-NMR) instrument at $400 \mathrm{MHz}$ (or $500 \mathrm{MHz}$ ) for ${ }^{1} \mathrm{H}-\mathrm{NMR}$ and $100 \mathrm{MHz}$ (or $125 \mathrm{MHz}$ ) for ${ }^{13} \mathrm{C}-\mathrm{NMR}$, respectively, in $\mathrm{CDCl}_{3}$. ESIMS were obtained with a Bruker APEX II mass spectrometer. Gravity column chromatography was performed on silica gel (230-400 mesh, Merck). TLC was carried out on precoated Kieselgel 60 F254 (0.2 mm, Merck) and spots were visualized by spraying with $10 \% \mathrm{H}_{2} \mathrm{SO}_{4}$ solution followed by heating. High-performance liquid chromatography (HPLC) was performed using a system comprised of a Hitachi L-7100 pump and a Rheodyne 7725 injection port. A preparative normal phase column $(250 \times 21.2 \mathrm{~mm}, 5 \mu \mathrm{m})$ was used for HPLC.

\subsection{Animal Material}

The specimen of Theonella swinhoei was collected by scuba divers at a depth of 15-20 m from coral reefs off the coast of Pingtung, Taiwan. A voucher specimen was deposited in the National Museum of Marine Biology and Aquarium, Taiwan (specimen no. 2011SP-2). Taxonomic identification was performed by Prof. Wen-Been Chang of the National Museum of Marine Biology \& Aquarium, Pingtung, Taiwan.

\subsection{Extraction and Separation}

The sponge Theonella swinhoei (2.2 $\mathrm{kg}$ fresh wt) stored frozen and then freeze dried. The freeze-dried material $(590 \mathrm{~g})$ was minced and extracted exhaustively with EtOAc $(5 \times 2 \mathrm{~L})$. The EtOAc extract was evaporated to yield a residue (11.9 g), which was subjected to open column chromatography on silica gel eluting with $n$-hexane (H)-EtOAc (E) gradient and EtOAc (E)-acetone (A) gradient, to give 12 fractions: Fr-1 (eluted by H-E 100:1), Fr-2 (eluted by H-E 50:1), Fr-3 (eluted by H-E 30:1), Fr-4 (eluted by H-E 20:1), Fr-5 (eluted by H-E 10:1), Fr-6 (eluted by H-E 8:1), Fr-7 (eluted by H-E 5:1), Fr-8 (eluted by H-E 3:1), Fr-9 (eluted by H-E 1:1), Fr-10 (eluted by EtOAc), Fr-11 (eluted by E-A 1:1) and Fr-12 (eluted by acetone). Fraction $2(250 \mathrm{mg})$, was subjected to normal phase HPLC (Hibar $250 \times 21.2 \mathrm{~mm}$, Supelco, silica gel 60,5 $\mu \mathrm{m})$, using $n$-hexane-EtOAc (25:1) as eluent, to afford four subfractions (A1-A4). Subfraction A1 (50 mg) was separated by normal phase HPLC using 
$n$-hexane-EtOAc (25:1) to afford 2 (25.5 mg, 0.21\% dry wt of extract) and $\mathbf{3}(1.8 \mathrm{mg}, 0.015 \%$ dry wt of extract). Subfraction A3 (120 mg) was also purified by normal phase HPLC using $n$-hexane-EtOAc $(15: 1)$ to afford 5 ( $55 \mathrm{mg}, 0.46 \%$ dry wt of extract). Fraction $5(2.5 \mathrm{~g})$, was further separated by silica gel open column chromatography with gradient elution ( $n$-hexane-EtOAc, 10:1 to 5:1) to afford 4 ( $1.2 \mathrm{~g}, 10.1 \%$ dry wt of extract). Fraction $7(250 \mathrm{mg})$, was further separated by normal phase HPLC ( $n$-hexane-EtOAc, 5:1) to yield six subfractions (B1-B6). Subfraction B3 (30 mg) was separated by normal phase HPLC using $n$-hexane-acetone (6:1) to afford 1 (12.5 mg, $0.11 \%$ dry wt of extract).

Theonellasterol K (1): white powder; $[\alpha]^{24}{ }_{\mathrm{D}}=+82\left(c 0.2, \mathrm{CHCl}_{3}\right)$; IR (neat) $v_{\max } 3362,3251,2956$, 2870, 1644, 1451 and $1376 \mathrm{~cm}^{-1} ;{ }^{1} \mathrm{H}$ and ${ }^{13} \mathrm{C}$ NMR data, see Table 1; ESIMS $m / z$ 481 [50, $\left.(\mathrm{M}+\mathrm{Na})^{+}\right]$; HRESIMS $m / z 481.3659$ (calcd. for $\mathrm{C}_{30} \mathrm{H}_{50} \mathrm{O}_{3} \mathrm{Na}, 481.3657$ ).

Acetyltheonellasterol (2): white powder; $[\alpha]^{24}{ }_{\mathrm{D}}=-3\left(c\right.$ 1.0, $\left.\mathrm{CHCl}_{3}\right)$; IR (neat) $v_{\max } 2957,1744$, 1644, and $1373 \mathrm{~cm}^{-1} ;{ }^{1} \mathrm{H}$ and ${ }^{13} \mathrm{C}$ NMR data, see Table 1; ESIMS $\mathrm{m} / z$ $491\left[80,(\mathrm{M}+\mathrm{Na})^{+}\right]$; HRESIMS $m / z 491.3862$ (calcd. for $\mathrm{C}_{32} \mathrm{H}_{52} \mathrm{O}_{2} \mathrm{Na}, 491.3865$ ).

Acetyldehydroconicasterol (3): white powder; $[\alpha]^{24}=-5$ (c 0.1, $\left.\mathrm{CHCl}_{3}\right)$; IR (neat) $v_{\max } 2927,1742$, and $1376 \mathrm{~cm}^{-1}$; ${ }^{1} \mathrm{H}$ and ${ }^{13} \mathrm{C}$ NMR data, see Table 1; ESIMS $m / z 475$ [100, $\left.(\mathrm{M}+\mathrm{Na})^{+}\right]$; HRESIMS $m / z 475.3555$ (calcd. for $\mathrm{C}_{31} \mathrm{H}_{48} \mathrm{O}_{2} \mathrm{Na}, 475.3552$ ).

Acetylation of 4: A solution of $4(10.0 \mathrm{mg})$ in pyridine $(0.2 \mathrm{~mL})$ was mixed with $\mathrm{Ac}_{2} \mathrm{O}(0.2 \mathrm{~mL})$, and the mixture was stirred at $\mathrm{rt}$ for $24 \mathrm{~h}$. After evaporation of excess reagent, the residue was subjected to column chromatography over Si gel using $n$-hexane-EtOAc (7:1) to yield 2 (10.5 mg, 95\%). The specific rotation $\left[[\alpha]^{24}=-3\left(c 0.5, \mathrm{CHCl}_{3}\right)\right]$ was in full agreement with that of the natural product 2 .

\subsection{Cytotoxicity Testing}

Cell lines were purchased from the American Type Culture Collection (ATCC). Cytotoxicity assays of compounds 1-5 were performed using the MTT [3-(4,5-dimethylthiazol-2-yl)-2,5-diphenyltetrazolium bromide] colorimetric method [22,23].

\subsection{Molecular Mechanics Calculations}

Implementation of the MM2 force filed in Chem3D Pro software [24] was used to calculate the molecular models.

\section{Conclusions}

A series of new 4-methylenesterols were isolated from the sponge Theonella swinhoei [8-21]. Our continued investigation of the chemical constituents of sponge $T$. swinhoei has again led to the isolation of three new 4-methylenesterols (1-3) and two known 4-methylenesterols (4 and 5). Compound 1 exhibited significant cytotoxicity against HCT-116, K562 and Molt 4 cells, and moderate to weak cytotoxicity against DLD-1, MCF-7, and MDA-MB-231 cells. In addition, compound 2 exhibited weak cytotoxicity toward K562 and Molt 4 cell lines. However, the new compound $\mathbf{3}$ and the other known compounds had no significant activity. According to our research, metabolite $\mathbf{1}$ exhibited 
significant cancer cells inhibitory activity. This result suggests that $\mathbf{1}$ should be subjected to further biomedical investigation.

\section{Acknowledgements}

This work was supported by grants from the Ministry of Education (00C030205), the National Museum of Marine Biology \& Aquarium and the National Science Council (NSC 101-2325-B-291-001), Taiwan, awarded to J.-H. Su.

\section{References}

1. Andavan, G.S.B.; Lemmens-Gruber, R. Cyclodepsipeptides from marine sponges: Natural agents for drug research. Mar. Drugs 2010, 8, 810-834.

2. Ebada, S.S.; Lin, W.; Proksch, P. Bioactive sesterterpenes and triterpenes from marine sponges: Occurrence and pharmacological significance. Mar. Drugs 2010, 8, 313-346.

3. Blunt, J.W.; Copp, B.R.; Keyzers, R.A.; Munro, M.H.G.; Prinsep, M.R. Marine natural products. Nat. Prod. Rep. 2012, 29, 144-222.

4. Essack, M.; Bajic, V.B.; Archer, J.A.C. Recently confirmed apoptosis-inducing lead compounds isolated from marine sponge of potential relevance in cancer treatment. Mar. Drugs 2011, 9, 1580-1606.

5. Kim, G.-Y.; Kim, W.-J.; Choi, Y.H. Pectenotoxin-2 from marine sponges: A potential anti-cancer agent—a review. Mar. Drugs 2011, 9, 2176-2187.

6. Laport, M.S.; Santos, O.C.S.; Muricy, G. Marine sponges: Potential sources of new antimicrobial drugs. Curr. Pharm. Biotechnol. 2009, 10, 86-105.

7. Sagar, S.; Kaur, M.; Minneman, K.P. Antiviral lead compounds from marine sponges. Mar. Drugs 2010, 8, 2619-2638.

8. Kho, E.; Imagawa, D.K.; Rohmer, M.; Kashman, Y.; Djerassi, C. Sterols in marine invertebrates. 22. Isolation and structure elucidation of conicasterol and theonellasterol, two new 4-methylene sterols from the Red Sea sponges Theonella conica and Theonella swinhoei. J. Org. Chem. 1981, 46, 1836-1839.

9. Qureshi, A.; Faulkner, D.J. 7 $\alpha$-Hydroxytheonellasterol, a cytotoxic 4-methylene sterol from the Philippines sponge Theonella swinhoei. J. Nat. Prod. 2000, 63, 841-842.

10. Kobayashi, M.; Kawazoe, K.; Katori, T.; Kitagawa, I. Marine natural products. XXX. Two new 3-keto-4-methylene steroids, theonellasterone and conicasteone, and bistheonellasterone, from the Okinawan marine sponge Theonella swinhoei. Chem. Pharm. Bull. 1992, 40, 1773-1778.

11. Inouye, Y.; Sugo, Y.; Kusumi, T.; Fusetani, N. Structure and absolute sterochemistry of bisconicasterone from the marine sponge Theonella swinhoei. Chem. Lett. 1994, 23, 419-420.

12. Sugo, Y.; Inouye, Y.; Nakayama, N. Structures of nine oxygenated 4-methylene sterols from Hachijo marine sponge Theonella swinhoei. Steroids 1995, 60, 738-742.

13. Umeyama, A.; Shoji, N.; Enoki, M.; Arihara, S. Swinhosterols A-C, 4-methylene secosteroids from the marine sponge Theonella swinhoei. J. Nat. Prod. 1997, 60, 296-298.

14. Zhang, H.J.; Yi, Y.H.; Lin, H.W. Oxygenated 4-methylidene sterols from the South China Sea sponge Theonella swinhoei. Helv. Chim. Acta 2010, 93, 1120-1126. 
15. Angawi, R.F.; Calcinai, B.; Cerrano, C.; Dien, H.A.; Fattorusso, E.; Scala, F.; Taglialatela-Scafati, O. Dehydroconicasterol and aurantoic acid, a chlorinated polyene derivative, from the indonesian sponge Theonella swinhoei. J. Nat. Prod. 2009, 72, 2195-2198.

16. De Marino, S.; Sepe, V.; D’Auria, M.V.; Bifulco, G.; Renga, B.; Petek, S.; Fiorucci, S.; Zampella, A. Towards new ligands of nuclear receptors. Discovery of malaitasterol A, an unique bis-secosterol from marine sponge Theonella swinhoei. Org. Biomol. Chem. 2011, 9, 4856-4862.

17. De Marino, S.; Ummarino, R.; D’Auria, M.V.; Chini, M.G.; Bifulco, G.; Renga, B.; D’Amore, C.; Fiorucci, S.; Debitus, C.; Zampella, A. Theonellasterols and conicasterols from Theonella swinhoei. Novel marine natural ligands for human nuclear receptors. J. Med. Chem. 2011, 54, 3065-3075.

18. De Marino, S.; Ummarino, R.; D’Auria, M.V.; Chini, M.G.; Bifulco, G.; D’Amore, C.; Renga, B.; Mencarelli, A.; Petek, S.; Fiorucci, S.; Zampella, A. 4-Methylenesterols from Theonella swinhoei sponge are natural pregnane-X-receptor agonists and farnesoid-X-receptor antagonists thatmodulate innate immunity. Steroids 2012, 77, 484-495.

19. Sepe, V.; Ummarino, R.; D’Auria, M.V.; Chini, M.G.; Bifulco, G.; Renga, B.; D’Amore, C.; Debitus, C.; Fiorucci, S.; Zampella, A. Conicasterol E, a small heterodimer partner sparing farnesoid $\mathrm{X}$ receptor modulator endowed with a pregnane $\mathrm{X}$ receptor agonistic activity, from the marine sponge Theonella swinhoei. J. Med. Chem. 2012, 55, 84-93.

20. Chini, M.G.; Jones, C.R.; Zampella, A.; D’Auria, M.V.; Renga, B.; Fiorucci, S.; Butts, C.P.; Bifulco, G. Quantitative NMR-derived interproton distances combined with quantum mechanical calculations of ${ }^{13} \mathrm{C}$ chemical shifts in the stereochemical determination of conicasterol $\mathrm{F}$, a nuclear receptor ligand from Theonella swinhoei. J. Org. Chem. 2012, 77, 1489-1496.

21. Renga, B.; Mencarelli, A.; D’Amore, C.; Cipriani, S.; D’Auria, M.V.; Sepe, V.; Chini, M.G.; Monti, M.C.; Bifulco, G.; Zampella, A.; Fiorucci, S. Discovery that theonellasterol a marine sponge sterol is a highly selective FXR antagonist that protects against liver injury in cholestasis. PloS One 2012, 7, e30443.

22. Alley, M.C.; Scudiero, D.A.; Monks, A.; Hursey, M.L.; Czerwinski, M.J.; Fine, D.L.; Abbott, B.J.; Mayo, J.G.; Shoemaker, R.H.; Boyd, M.R. Feasibility of drug screening with panels of human tumor cell lines using a microculture tetrazolium assay. Cancer Res. 1988, 48, 589-601.

23. Scudiero, D.A.; Shoemaker, R.H.; Paull, K.D.; Monks, A.; Tierney, S.; Nofziger, T.H.; Currens, M.J.; Seniff, D.; Boyd, M.R. Evaluation of a soluble tetrazolium/formazan assay for cell growth and drug sensitivity in culture using human and other tumor cell lines. Cancer Res. 1988, 48, $4827-4833$.

24. Chem3D Ultra, version 9.0.1; CambridgeSoft Corporation: Cambridge, MA, USA, 2005.

Samples Availability: Available from the authors.

(C) 2012 by the authors; licensee MDPI, Basel, Switzerland. This article is an open access article distributed under the terms and conditions of the Creative Commons Attribution license (http://creativecommons.org/licenses/by/3.0/). 